\title{
Empowerment of rural community through the development of renewable electricity
}

\section{Dessy Rachmawatie ${ }^{1,2 *}$; Ernan Rustiadi ${ }^{3}$; Akhmad Fauzi ${ }^{4}$; Bambang Juanda ${ }^{5}$}

1) Study Program of Economics Science. Faculty of Economics and Business, Universitas Muhammadiyah Yogyakarta, Indonesia

2) Postgraduated Study Program of Regional Planning Development and Rural Science, Faculty of Economics and Management, IPB University, Indonesia

3) Department of Regional Planning, Faculty of Agriculture, IPB University, Indonesia

4) Department of Resource Economics and Environmental, Faculty of Economics and Management, IPB University, Indonesia

5) Department of Economics Science, Faculty of Economics and Management, IPB University, Indonesia

* To whom correspondence should be addressed. E-mail: dessyvalue@gmail.com

\begin{tabular}{|l|l|l|l|l|}
\hline DOI: & Received: & Revised: & Accepted: & Published: \\
10.22437/ppd.v8i1.8077 & 17.11 .2019 & 09.03 .2020 & 13.03 .2020 & 12.06 .2020 \\
\hline
\end{tabular}

\begin{abstract}
The purpose of this study is to analyze the empowerment of electricity beneficiaries through community empowerment activities following the use of wind and solar renewable energy (PLTH) in Pantai Baru. To achieve these objectives, the data collection in this study was carried out using a structured research questionnaire to 68 PLTH electricity beneficiaries in Pantai Baru, where they are also managers of tourism business in Pantai Baru.This study uses a frequency distribution analysis method to identify: (1) the profile of renewable electricity beneficiaries and (2) determine the extent of empowerment renewable energy electricity beneficiaries in Pantai Baru. The results showed that the characteristics of the beneficiaries were generally of a mature age, had a clear direction of life and goals, and had and adequate level of education. Furthermore, in terms of the empowerment indicators used in this study, they are rated as high. Thus, this study indicates that the community empowerment activities through the development of renewable energy have an impact to the empowerment of PLTH electricity beneficiaries in Pantai Baru.
\end{abstract}

Keywords: Electricity beneficiaries, Empowerment, Rural community development.

JEL Classifications: A13, C10, P25, R58, Q30, Z13.

\section{INTRODUCTION}

Yogyakarta Special Region (Daerah Istimewa Yogyakarta/DIY) Province is one of Indonesia's provinces with no reserves or potential for non-renewable primary energy resources. Thus, the demand for non-renewable energy, such as petroleum, coal and gas, has so far been supplied from other regions. Electricity is also supplied from the Java- 
Madura-Bali (JAMALI) interconnection network since there are no power plants that satisfy the electricity demand of the people of Yogyakarta.

In addition to the $500 \mathrm{kV}$ and $150 \mathrm{kV}$ transmission systems, the main supplies for electricity needs in the Central Java Province and DIY Province are Tambaklorok PLTU/ PLTGU, Mrica PLTU, the Cilacap PLTU and the Dieng PLTP. On the other hand, the energy consumption of the DIY Province continued to increase from 1,603,700 BOE to $1,817,900 \mathrm{BOE}$ in 2011-2015. It is also projected that the energy consumption level of the DIY Province will begin to grow to $2,138,900$ to $2,529,600$ BOE in 2020-2025 (Badruzzaman, 2013). It is predicted as well, on the basis of a review of current conditions, that the DIY Province will require a high supply of energy. Given the current state of energy availability, it is unlikely that these needs can be met only by relying on non-renewable energy supplies.

The potential for renewable energy in the DIY Province based on the results of the CAREPI study (2009) shows that the wind, energy and solar energy resources is the most potential of renewable energy resources to be developed in the Yogyakarta region (Table 1).

Table 1. Potential of renewable energy in DIY Province

\begin{tabular}{lc}
\hline Source of Renewable Energy & Energy Potential $(\mathrm{kW})$ \\
\hline Water & 750 \\
Photovoltaic & 3,000 \\
Wind & 16,000 \\
Biomass & 2,750 \\
\hline Total & 22,500 \\
Source: CAREPI (2009) &
\end{tabular}

Renewable energy is one of the most efficient ways to achieve sustainable development (Goldemberg, 2007). One of the main tasks of this century would be to manage a transition process towards a sustainable energy system (Haas, Watson and Eichhammer, 2008). Renewable energy use in the last five decades has been driven by environmental, social and economic factors (Gado \& El-Zeftawy, 2009; Katti \& Khedkar, 2005; Wang, Jing, Zhang and Zhao, 2009; Bernal \& Dufo, 2009). In order to ensure that the renewable energy (RE) resources are optimized, there have been many attempts by researchers to enhance sustainability and the use of renewable energy.

Based on the potential of renewable energy in the DIY Province, it is very likely to develop electrical energy from renewable energy sources. This is reinforced by the Government Regulation Number 3 of 2005 concerning electricity, which specifically states that the role of the regional government, as outlined in Article 2A, namely "Regional Government provides electricity to help disadvantaged groups of society, construction of electricity supply facilities in undeveloped areas, development electricity in remote areas and rural electricity development." Through this regulation, regional governments produce energy management policies. Energy management policies of the DIY Province include:

1. Development of energy infrastructure to increase energy supply so that more consumers have access to energy, including:

a. Creation of regulations for energy development and use activities;

b. Increased investment in the construction of rural electricity networks, especially in remote and isolated areas; 
2. Protection of disadvantaged communities, in particular communities in remote and rural areas by community empowerment to produce energy independently, both for the benefit of lighting, cooking and small-scale economic development;

3. Partnership between government and industry for the growth of the energy sector in the regions;

4. Research and development, as well as education and training for the advancement of technology and human resources;

5. Coordination between sectors at regional and national level to support energy supply in the regions.

The provision of access to electricity through the development of renewable energy is a strategic program for villages, because (1) electricity is one of the basic needs of the community, so that the provision of electricity is an effort by the government to meet the basic needs of the entire community, both those living in cities and in the villages. The existence of electricity in the village is expected to empower rural communities from backwardness and limitations in accessing electricity, (2) providing access to electricity for villages is expected to reduce the disparities between villages and cities as well as the disparities between regions. Access to electricity in the village is expected to encourage and contribute to rural economic growth and communities, (3) business case for renewable energy sources encourage investment activities (Peura \& Hyttinen, 2011; Masini \& Menichetti, 2012) and benefits beyond business profitability could be significant. The potential regional economic and employment impacts are among the most powerful drivers of sustainable energy. For instance, it has repeatedly been argued that renewable energy sources create more employment than conventional energy (Sastresa, Uson, Bribi \& Scarpellini, 2010), (4) regional value-added among others monetary aspects (cost savings, enhanced purchasing power, creation of jobs, tax income, social, ecological and ethical aspects and improved vitality) would be remarkable if all the money which currently flows out remained within the region (Hillebrand, Buttermann, Behringer, Bleuel, 2006; Lehr, Nitsch, Kratzat, Lutz, \& Edler, 2008; Moreno \& Lopez, 2008; Thomley, Rogers, \& Huang, 2008; Blanco \& Rodrigues, 2009; Hoffmann, 2009; del Río \& Burguillo, 2009; Openshaw, 2010; Sastresa, Uson, Bribi, \& Scarpellini, 2010; Dalton \& Lewis, 2011; Masini \& Menichetti, 2012).

Access to electrical power is a crucial factor in reducing poverty in remote areas where human development factors are typically marginal (Shyu, 2014; Valer, 2014). The Human Development Index (HDI) factor is improved as the living standard of the population improves, such as better use of electricity, better education, higher net income per capita and the usage of electrical devices, new industries, and jobs. Due to its effect on the HDI, technical design has been proposed as an important aspect by many authors (Gomez \& Silveira, 2010). The HDI approach depends on four key columns that must bolster each vital development activity in order to open the doors of growth for individuals and turning them into masters of their own advancement. These four standards are as (ul Haq, 1995): 1) Equity and Diversity; 2) Sustainability; 3) Productivity; 4) Empowerment.

Empowerment is associated with processes by which individuals are aware of their interests and how these relate to those of others. Empowerment, however, is more than simply opening up access to decision-making; it must also provide processes that allow people to see themselves as competent and entitled to fill the decision-making space (Rowlands, 1995). Thus, a more precise concept of empowerment refers to an 
improvement of the ability, capacity, productivity, creativity and community independence to create greater opportunities for access and control of various resources.

Stewart (1994) notes that empowerment is quite simple, a highly practical and productive way to get the most out of yourself and your staffs. It can therefore be concluded that empowerment is not an objective of growth, but a tool for achieving development goals. Community empowerment is a strategy in development. As a concept of economic development, it encapsulates the social values that exist in society. Empowerment is described as a process in which individuals and organized groups can envision their world differently and achieve the vision by shifting the relations of power that hold them in poverty (Eyben, Kabeer \& Cornwall, 2008). We chose the latter definition because it defines the role of critical consciousness, acknowledges that empowerment can happen at both the individual and collective level, and makes explicit reference to power.

Empowerment activities for tourism business managers in Pantai Baru are one of the main pillars that contribute to the process of developing sustainable hybrid electricity at Pantai Baru, which has been developed since 2010, namely the empowerment of electricity beneficiaries of Hybrid Power Plants (PLTH). Since the location was developed as a site for the development of PLTH electric energy, this effort has transformed the face of Pantai Baru into a potential new tourism development area in Bantul Regency. After the development of PLTH electricity in Pantai Baru, many community empowerment programs have reached the region, from the central, regional, and academic governments programs. The empowerment program focuses on the potential and needs of electricity of the beneficiaries who are business operators in Pantai Baru. The challenge they usually face is the issues of knowledge, skills, facilities and financial empowerment.

Community empowerment is a basic element that allows a society to survive and, in a dynamic sense, evolves and enjoys a much better life. The goal of the community empowerment project in rural areas is to improve human capital, increase capacity, and build business opportunities based on the potential, expectations and needs of the community. Therefore, through electrification activities in rural areas, it is hoped that the community will not only have access to electricity, but will also be able to empower the beneficiaries of PLTH electricity directly and indirectly to the local community. It is also hoped that this activity would increase the empowerment of the local community, in particular the beneficiaries of renewable hybrid electricity in Pantai Baru. Specifically, the objectives of this study are: (1) to determine the characteristics of electricity beneficiaries, environmental characteristics and group support following the development of PLTH electricity in Pantai Baru; (2) to examine the empowerment of electricity beneficiaries following the development of PLTH electricity in Pantai Baru.

\section{METHODS}

\section{Types and sources of data}

The aim of this study is to provide an overview of the level of empowerment of PLTH electricity beneficiaries following the development of PLTH in Pantai Baru. The data used are primary data obtained from field observations. This research consists of a survey of 68 respondents, who are beneficiaries of PLTH electricity. 


\section{Data collection techniques}

Data collection uses two methods, namely in-depth interviews and interviews with respondents using census methods. Both data collection techniques are used as the number of samples is equal to the population. Data collection refers to the intention of obtaining a picture of the level of empowerment of beneficiaries following the development of PLTH in Pantai Baru. The results of the in-depth interviews provide proof of valid conditions for research purposes and no number of key informants are required (Berg, 2001). Key questions are designed for the purpose of in-depth interviews and the interview process by a key information questionnaire.

The in-depth interview approach provides qualitative data comprising two main sections, namely information on the characteristics of key informants as well as the history of PLTH developed in Pantai Baru. The census method provides qualitative data comprising four major parts, including information on the characteristics of the respondents, environmental aspects that support PLTH, and group support. Interviews were conducted in October 2017 with 7 key informants from the central government, local government and PLTH operational officers.

The results of the interviews provide evidence of the present condition of PLTH electricity beneficiaries. The interview uses a survey form that generates primary data and is tabulated for statistical purposes. Any relevant documents complement the interpretation of the research carried out (Bryman, 2004). The document shall include as a reference all written material relating to the focus of research and publication.

Table 2.Number of key informants and respondents

\begin{tabular}{lclc}
\hline \multicolumn{1}{c}{ Key Informants } & & \multicolumn{2}{c}{ Respondent } \\
\hline Representative & Person & Representative & Person \\
\hline Central Government & 1 & Cullinary Traders & 56 \\
Head of Operational PLTH & 1 & Toilet Owner & 3 \\
Headman & 1 & Pool Owner & 2 \\
Hamlet Head & 1 & Cloths Seller & 2 \\
Head of POKDARWIS & 1 & Game Owner & 1 \\
Head of POKGIAT & 1 & Snack Merchant & 2 \\
Head of The Farmers Group & 1 & Fishmonger & 2 \\
Head of The Stock Farmers Group & 1 & & 68 \\
\hline Total & 8 & & \\
\hline
\end{tabular}

Source: Research Observation Results. 2017.

\section{Data processing and analysis}

Data analysis is carried out by calculating the score and represented in a descriptive manner. The component of PLTH beneficiaries of this study consists of 4 (four) indicators: the adaptability, the ability to manage businesses, the ability to make decisions and the ability to cooperate. Each question is scored (1-4), with the following criteria: low, medium, high and very high. The responses of the respondents are then classified in the criteria interval.

\section{Operational definitions of research and measurement variables}

Community empowerment is a strategy that focuses on how to provide a proportionate role so that the community can play an active role in social activities. Hubeis (2002) states that community empowerment is an embodiment of community capacity building that is nuanced in empowering human capital through institutional growth starting from the central to the village level. It is in line with the development of the people's socio-economic system, facilities and infrastructure, as well as development, 
namely: assistance that can facilitate community engagement, counseling that functions to respond to and track development in the community, and services that act as an aspect of controlling the accuracy of the allocation of physical and non-physical resource properties.

The essence of the concept of empowerment under cis power, that is, power to change. Fujikake (2008) describes the indicators of the level of empowerment, namely the level of participation, opinion opening, change of consciousness, taking action, caring and cooperation, creativity, setting new goals, negotiation, satisfaction, self-confidence, financial management and decision making.

Empowering the community in the context of this research is that the beneficiaries of PLTH electricity are intended to improve the dignity of the people who are unable to avoid the poverty and underdevelopment pitfalls in their present situation (Hendratmoko \& Marsudi, 2010).

The level of empowerment refers to the ability possessed by electrical beneficiaries in the form of interrelation of individual, perceptions of their environmental abilities, collective actions and abilities to achieve goals as well as ability to overcome their problems to meet their needs. In this study, the level of empowerment was assessed using four indicators: the adaptability, the ability to manage a business, the ability to make decisions and the ability to cooperate. Measurement parameters were determined from the respondents' answers to questions posed in the research questionnaire using a Likert scale with four answer choices (very low to high). Strong beneficiaries are those who have the adaptability to situations of social change, manage businesses, make decisions and work together.

a) Adaptability is the knowledge, attitudes and skills of PLTH electricity beneficiaries in dealing with all causes of change from outside, such as: market changes, technologies and so on. Adaptation means adaptation to the environment, which can involve changes to the environmental conditions or vice versa (Gerunga, 1991). The adaptability in this study is demonstrated by the knowledge, attitudes and skills of the beneficiaries in the face of changes in the form of PLTH technology development in Pantai Baru.

b) Ability to manage a business is the knowledge, attitudes and technical skills possessed by PLTH electricity beneficiaries in the tourism industry of Pantai Baru. It also means that the beneficiaries have the ability to plan, keep books simple and be brave to bear business risks.

c) Ability to make decisions is the knowledge, attitudes and skills possessed by PLTH electricity beneficiaries to make decisions, overcome problems, handle pressure and take responsibility for the acts on the basis of their participation and active role in the tourism business activities in Pantai Baru.

d) Ability to cooperate is the knowledge, attitudes and skills of PLTH electricity beneficiaries to establish cooperation in groups, between groups, capital, food suppliers and institutions to boost the tourism businesses in Pantai Baru.

\section{Analysis method}

There are two analytical methods used in this study: (1) frequency distribution analysis to describe the profile of the respondents based on the construct variables of individual characteristics: age, education, business experience and motivation of the respondents; and (2) frequency distribution analysis to determine the empowerment of PLTH electricity beneficiaries, based on the following indicators: adaptability, ability to manage business, ability to make decisions and ability to cooperate. 
Table 3. Matrix of achievement of objectives for analysis: the empowerment of PLTH electricity beneficiaries after the development of PLTH electricity in Pantai Baru

\begin{tabular}{|c|c|c|c|c|}
\hline Objectives & Data & Source & Analysis & Results \\
\hline $\begin{array}{l}\text { (1) To identified the } \\
\text { characteristics } \\
\text { ofindividual: age, } \\
\text { education, business } \\
\text { experience, household } \\
\text { income and motivation } \\
\text { of PLTH electricity } \\
\text { beneficiaries. }\end{array}$ & Questionnaire & $\begin{array}{l}\text { Observation } \\
\text { and } \\
\text { interview }\end{array}$ & $\begin{array}{l}\text { Descriptive of } \\
\text { the variable: } \\
\text { age, } \\
\text { education, } \\
\text { business } \\
\text { experience } \\
\text { and } \\
\text { motivation }\end{array}$ & $\begin{array}{l}\text { Description of } \\
\text { individual } \\
\text { characteristics: age, } \\
\text { education, business } \\
\text { experience, and } \\
\text { motivation of PLTH } \\
\text { electricity } \\
\text { beneficiaries. }\end{array}$ \\
\hline $\begin{array}{l}\text { (2) Measuring the } \\
\text { empowerment of PLTH } \\
\text { electricity } \\
\text { beneficiaries. }\end{array}$ & $\begin{array}{l}\text { Questionnaire } \\
\text { and key } \\
\text { infromants }\end{array}$ & $\begin{array}{l}\text { Observation } \\
\text { and } \\
\text { interview }\end{array}$ & Likert Scale & $\begin{array}{l}\text { Theempowerment of } \\
\text { PLTH electricity } \\
\text { beneficiaries after the } \\
\text { development of } \\
\text { electricity in Pantai } \\
\text { Baru. }\end{array}$ \\
\hline
\end{tabular}

Source: Rachmawatie, 2019.

\section{RESULTS AND DISCUSSION}

\section{Individual characteristics of PLTH electricity beneficiaries}

According to Lionberger (1982), Rogers \& Shoemaker (1971), Spencer \& Spencer (1993), Mardikanto (1993) and Hardiani, Prihanto \& Junaidi (2019) individual characteristics are inherent in a person, underlying behavior related to aspects of life, including age, sex, position, social status and religion. Each individual has characteristics which are not shared by other individuals. Lionberger \& Gwin (1982) suggest that the internal factors influencing the pace in adopting include: age, level of education, socioeconomic status, willingness to take risks, attitudes to change, and motivation. Individual characteristics of PLTH electricity beneficiaries can be found in Table 3.

Table 3. Characteristics of individual, PLTH electricity beneficiaries

\begin{tabular}{|c|c|c|c|}
\hline Indicators & Category & Frequency & Percentage (\%) \\
\hline \multirow[t]{3}{*}{ Age } & $18-40$ years & 23 & 33.82 \\
\hline & $41-59$ years & 38 & 55.88 \\
\hline & $\geq 60$ years & 7 & 10.29 \\
\hline \multirow[t]{2}{*}{ Gender } & Female & 54 & 79.41 \\
\hline & Male & 14 & 20.59 \\
\hline \multirow[t]{4}{*}{ Level of Education } & Primary School $(\leq 6)$ years & 21 & 30.88 \\
\hline & Junior High School $(7-9)$ years & 7 & 10.29 \\
\hline & Senior High School $(10-12)$ years & 37 & 54.41 \\
\hline & College $(>12)$ years & 3 & 4.41 \\
\hline Business & $<2$ years & 4 & 5.88 \\
\hline \multirow[t]{3}{*}{ Experience } & $2-3$ years & 8 & 11.76 \\
\hline & 4-5 years & 4 & 5.88 \\
\hline & $>5$ years & 52 & 76.47 \\
\hline \multirow[t]{4}{*}{ Motivation } & Very low & 0 & 0.00 \\
\hline & Low & 2 & 2.94 \\
\hline & Medium & 14 & 20.59 \\
\hline & High & 52 & 76.47 \\
\hline
\end{tabular}

Source: Analysis Results. 2019. 
Age

Age can be a sign of development related to the task of development, learning process, survival, and the various aspects that lie behind it (Monks, Knoers and Haditono, 2001). Based on the observations, 55.88 percent of electricity beneficiaries are aged 4159 years, 33.82 percent are aged 18-40 years, and 10.29 percent of them are 41 to 59 years old. At the age of 41 - 59 years, individuals make adjustments independently to life and social expectations. In general, at this age someone better understands the problems they face, so it is more stable to master themselves. Respondents in this age group mostly already had a life partner, had a main livelihood that can fulfill family needs, had a household life, had been through the period of guiding and caring for children, manage households, be able to take responsibilities as citizens, and find suitable and relevant social groups.

According to Hurlock (1980) the ability to control oneself develops with age. The theory says that as a person ages, the better he is in control, psychologically mature individuals will also be able to control their behavior because they have been able to consider what is good and what is not good for him.

\section{Gender}

The concept of gender has fundamental differences with the concept of sex (Hardiani, Hastuti, \& Junaidi, 2019). Gender is a trait of men and women based on sociocultural dimensions that are apparent from values and behavior (Santrock, 2003). The definition of gender has given birth to different roles, responsibilities, functions and even the space in which people move.

Electricity beneficiaries of this sample were mainly female at $79 \%$, while the rest of them were male at $21 \%$. The female respondents mostly had culinary business, while the male respondents had business in parking, toilet rental, children's game rental, swimming pool and fresh fish sales.

\section{Education}

Horton \& Hunt (2006) describe the functions of education as: 1) to prepare each member of the community so that they may make their own living; 2) to develop their own interests and talents for personal fulfillment and the interests of the general public; 3 ) to help preserve the culture of the community; 4) to build the skills required to engage in democracy.

The study indicates that PLTH electricity beneficiaries, in general, are senior high school graduates. This means that respondents have a moderate (sufficient) level of education. Adequate education allows a person to be faster and more experienced in acquiring and applying new information from outside. The education level also affects attitudes, actions and mindsets of individuals in the decision-making process to adopt technological innovations. The higher the education level of an individual, the easier the comprehension of the positive influence obtained by the implementation of technological advancement for himself and his family would be (Rachmawatie, 2005).

\section{Business experience}

Entrepreneurial experience is important in increasing knowledge and ability in expertise and skills in entrepreneurship. This relates to the experience of providing initial knowledge before acting in an effort so that this person unconsciously must have the ability to predict the results obtained from actions in the business. Entrepreneurial experience is the experience of an individual in entrepreneurship and understanding the system in running a business (Hisrich and Peters, 1998). Successful aspects of experience through challenges drawn from learning activities that not only convey messages, but 
members who get the opportunity to try. education, experience and entrepreneurship training from an early age can increase a person's potential to become an entrepreneur, in addition to the support of academics, social and business environment. Providing education and entrepreneurial experience to someone from an early age can increase one's potential to become an entrepreneur (Nuskhi \& Setiana, 2004; Gurbuz \& Aykol, 2008; Suharti \& Sirine, 2011).

The level of business experience of PLTH electricity beneficiaries is in the category of more than 5 years, with an average business experience of 6 years. Observation findings also reveal that the business carried out by the beneficiaries prior to the establishment of PLTH in Pantai Baru was agricultural, fishing, livestock, and trading businesses. This is because the geographical location of this region is the area of dry land agriculture, fisheries and livestock. In general, those who do business at Pantai Baru are those who were initially doing business at Pandansimo Beach prior to the development of PLTH. Pandansimo Beach was hit by the earthquake in 2006 and the area was devastated. So when, in 2008, Bantul Regency engaged in a number of activities following the earthquake, the residents of Ngentak Hamlet at that time thought about setting up a new business in Pantai Baru. They did it with the hopes that their social and economic life will be better after the earthquake. Thus, the business experience of the beneficiaries existed before the development of PLTH in Pantai Baru.

\section{Motivation}

The term "motive" is closely related to motion, which is a movement carried out by people that is often referred to as acts or behavior (Sobur, 2009). Blanchard and Thacker (2010) define motivation as direction, encouragement, persistence and the amount of effort a person expends to achieve a specific goal.

Based on the findings of observations, the motivation of PLTH electricity beneficiaries in Pantai Baru is classified as very high. In the aftermath of the 2006 earthquake in Yogyakarta, the residents of Ngentak, in particular, made quite a major change. Some of the villagers are relying their lives on business activities along the coast, both in the fisheries sector, dry land agriculture and in the trading business in Pandansimo Beach. Efforts to build PLTH on Pantai Baru in 2008 were greatly welcomed by the villagers, as they could replace the site of their businesses that had been destroyed on Pandansimo Beach during the earthquake.

\section{Empowerment of PLTH electricity beneficiaries}

The empowerment of the electricity beneficiaries is an aspect that enables the beneficiaries to survive and, in a dynamic sense, means developing themselves and making progress. Empowering the communication in this research means that the beneficiaries of PLTH electricity are intended to improve the dignity of people who are unable to avoid the poverty and underdevelopment pitfalls (Hendratmoko and Marsudi, 2010). The empowerment level of electricity beneficiaries in general is seen in Table 4.

The development of PLTH electricity in Pantai Baru is an effort by the central and regional government to facilitate electricity needs of the residents of the hamlet. Based on the results of the analysis, it can be seen from the four indicators of the empowerment level that they are relatively high. The high level of empowerment of PLTH electricity beneficiaries is inseparable from the role of the local government, along with the Activity Group (POKGIAT) which already exists in Poncosari Village, includes the Farmer Activity Group, Livestock Activity Group, and Fisheries Activity Group. Postdevelopment tourism in Pantai Baru is present by the Tourism Awareness Group (POKDARWIS) to provide knowledge as well as socialization and counseling of PLTH 
activities. It also provides mentoring and coaching groups through business activities to encourage the beneficiaries to have the adaptability, the ability to manage business, the ability to make decisions and the ability to cooperate in groups.

Adaptation has a sense that is to do things that are more acceptable by altering or adjusting, referring to the process and conditions of adaptation that have specific interpretations in certain scientific disciplines (Smith, Burton, Klein, \& Street, 1999). In this study, adaptability is the attempt made by electricity beneficiaries to obtain knowledge, attitudes and skills in the face of change from external, for example, changes in environmental conditions, changes in markets, changes in technology, and so on. Table 4 reveals that the level of adaptability of electricity beneficiaries is high at $64.7 \%$.

Resource and financial limitations ultimately push households to carry out various coping strategies (Tridakusumah, Elfina, Murdiyaningsih, Pioke, \& Bumulo, 2015). Reduction of loss of planting land by farmers in Pantai Baru following the development of PLTH has an impact on farmers to pursue alternative sources of income both as farmer and as non-farmer. Hua, Yan \& Zhang (2017) define livelihood diversification the farmers' strategy to fulfill the needs of their family. Communities in the village, in general, make use of all the opportunities they need to make a number of efforts, including making a living in addition to farming. The results of field observations indicate that 64.70 per cent of farmers (farmers, ranchers, fishermen, shrimp ponds, sand miners, culinary and pokdarwis) also do additional work outside of agriculture by performing business tourism in Pantai Baru, while the remaining 35.30\% do other work outside of farming and tourism businesses, such as civil servants, private workers and sand miners.

Table 4. Distribution of mean scores based on indicators of empowerment

\begin{tabular}{llcc}
\hline \multicolumn{1}{c}{ Empowerment of PLTH Electricity } & Beneficiaries & Frequency & Percentage (\%) \\
\hline Adaptability & Very low & 0 & 0.0 \\
& Low & 4 & 5.9 \\
& Medium & 20 & 29.4 \\
Ability to manage a business & High & 44 & 64.7 \\
& Very low & 0 & 0.0 \\
& Low & 0 & 0.0 \\
The ability to make decisions & Medium & 7 & 10.3 \\
& High & 61 & 89.7 \\
& Very low & 0 & 0.0 \\
The ability to cooperate & Low & 3 & 4.4 \\
& Medium & 16 & 23.5 \\
& High & 49 & 72.1 \\
& Very low & 0 & 0.0 \\
& Low & 0 & 0.0 \\
& Medium & 3 & 4.4 \\
\hline
\end{tabular}

The ability to manage business in this study refers to Meredith, Geoffrey, Robert, Nelson, Philip, \& Nick (2000), which stated that it is the ability to manage all the resources owned by an entrepreneur, both knowledge, attitudes and technical skills. In this context, it includes planning, making simple bookkeeping, calculating and taking risks, and finding new ways and technologies in managing their business to achieve their goals and overcome the problems. The findings of this analysis indicate that electricity 
beneficiaries have a fairly high level of ability to manage business equivalent to $57 \%$. The level of the ability to make decisions of PLTH electricity beneficiaries is high, at $72.06 \%$. It includes the willingness of beneficiaries to participate in the counseling and mentoring programs carried out by the local authority, along with the Activity Groups and Tourism Awareness Groups. It also includes the decision taking in the selecting suppliers that are relevant to the needs and the capability of PLTH electricity beneficiaries in managing businesses in Pantai Baru.

The ability to cooperate in this study refers to knowledge, attitudes and skills of electricity beneficiaries in groups, between groups, between institutions and so on in running a tourism business in Pantai Baru. Bachrum (2010) in Kuncono (2013) explained that the ability to cooperate was interpreted as an attempt to maintain and continue to evolve and improve continuously. It can be seen from the long-term nature of working relationship with suppliers and customers, as well as the continuous and increasing presence of productivity and profitability of the business. The high level of ability to cooperate between PLTH electricity beneficiaries in Pantai Baru is inseparable from the role of group support in Ngentak Hamlet particularly. Through the group activities, they are emotionally connected to each other, such that family ties are strongly felt when collecting data in the area. For instance, the price of food sold at Pantai Baru is fixed at the same price, and there is no different pricing for each stall, even though they sell the same type of food. The same refers to leasing prices and other service sectors. In addition, PLTH electricity beneficiaries, who use Pantai Baru as a tourism business location, are also willing to help set aside their income for the construction of tourism infrastructure facilities in Pantai Baru.

Activity Group (POKGIAT) and Tourism Awareness (POKDARWIS), founded as a non-profit organization of the village community, focused primarily on guidance and assistance, as well as ensuring the availability of human resources from POKDARWIS members. Meanwhile, tourism service actors, in this case, tourism business in Pantai Baru are profit-oriented and contribute to the welfare of POKDARWIS members. Both POKGIAT and POKDARWIS members are obliged to build synergies between institutions, self-help and self-service services both in villages and in districts and provinces.

\section{CONCLUSIONS AND RECOMMENDATIONS}

\section{Conclusions}

Based on the characteristics of the beneficiaries of PLTH electricity since the establishment of PLTH electricity in Pantai Baru, the beneficiaries are generally in a mature age, have a clear perspective on life and goals, and have an adequate level of education. Thus, they are able to understand the objectives of the coaching and mentoring programs conducted by outsiders to empower themselves in the future. Furthermore, they do usually have fairly strong business experience, since they had already had business experience in Pandansimo Beach before PLTH was established in Pantai Baru. Similarly, with the amount of tourism business revenue in Pantai Baru following the development of PLTH, their average income from tourism business was quite high compared to the Provincial Minimum Wage (UMP) of the DIY Province. The growing number of tourists to Pantai Baru has an effect on the rising number of PLTH electricity beneficiaries in the area.

Following the establishment of PLTH in Pantai Baru, the empowerment of the beneficiaries was relatively high. This is inseparable from the role of local government 
support, along with community groups, in mentoring, training and coaching through community empowerment activities. It was not only the government (central and regional) that encouraged empowerment of the Poncosari Village, but also academics. Thus, it can be concluded that PLTH in particular in Ngentak Hamlet and in general in Poncosari Village plays a role in promoting community empowerment activities both that have existed and that have not yet existed, such as Activity Groups (POKGIAT) and Tourism Awareness Groups (POKDARWIS). Through these activities, the local community is eventually able to explore all the potential possessed by itself and the potential of its area. In addition, the local community is able to take advantage of all the potentials and resources to enhance the lives and well-being of the entire village community.

Based on the results of the analysis, it was concluded that, by using the empowerment indicators used in this study, the adaptability, the ability to manage business, the ability to make decisions and the ability to cooperate of the electricity beneficiaries are rated as high. This is the product of a community empowerment process that has been initiated and developed by many parties in encouraging local communities to empower themselves. The results of this study have concluded that the empowerment activities cannot be separated from PLTH development in Pantai Baru and vice versa. They all complement each other in empowering the local community.

\section{Recommendations}

Recommendations are offered specifically to encourage the development of renewable energy in Pantai Baru. Investment cooperation scheme between the government and private institutions/agencies are needed to build new and renewable energy resources that have a potential to be established in the regions. The rules for cooperation in this area have been governed by Presidential Regulation Number 39 of 2014 concerning the List of Closed Business Sectors and Open Business Sectors with Requirements in the Investment Sector governing investment in the electricity sector in Indonesia.

The policy regulates the portion of investment policy between foreign investors and local investors based on generating capacity and infrastructure that will be developed. One of the goals of sustainable energy development is to increase investment in the energy and mineral resources sector, in particular renewable energy. This policy creates space not only for the central government and the private sector, but also for regional governments to establish a strong collaboration scheme between institutions in their respective regions to improve the capacity for sustainable renewable energy. In order to ensure that, this area can be used as a Regional-Owned Enterprise operated by the region in a professional manner which, in effect, will promote and stimulate industries that either exist or have the potential to be established in the regions.

In the case of renewable energy resources with sufficient electricity capacity, the electricity produced can be sold to PT. PLN (Persero). This matter has been governed by Material Regulation No. 21 of 2016 concerning Purchasing Electric Power by PT. PLN (Persero) from Biomass-Based Power Plants and Biogas-Based Power Plants. Investors tend to be more interested in things with low risks and big gains. If we look at the circumstances and challenges of the development of renewable energy, those which are related to the issue of equipment costs, technology and the guarantee of raw materials for power plants are one of the factors considered by investors to develop renewable energy in Indonesia. 


\section{REFERENCES}

Badruzzaman, Y. (2013). Energy roadmap in the Special Province of Yogyakarta. Journal of Applied Electrical Engineering (JTET), 2(1), 18-30.

Berg, B.L. (2001). Qualitative Research Methodes for The Social Sciences. New York (US): A Pearson Education Company.

Bernal, AJL., \& Dufo. LR. (2009). Simulation and optimization of stand-alone hybrid renewable energy systems. Renewable sustainable energy reviews, 13(8), 21112118.

Blanchard, P.N., \& Thacker, JW. (2010). Effective training: systems, strategies, and practices . New Jersey: Pearson Education.

Blanco, M.I., \& Rodrigues, G. (2009). Direct employment in the wind energy sector: an EU study. Energy Policy, 37(8), 2847- 2857. https://doi.org/10.1016/j.enpol.2009.02. 049 .

Bryman, A. (2004). Social Research Methods (second edition). New York (US): Oxford University Press. Inc.

CAREPI. (2009). Contributing to poverty alleviation through regional energy planning in Indonesia. Netherland: Intelligent Energy Europe

Dalton, G.J., \& Lewis, T. (2011). Metrics for measuring job creation by renewable energy technologies, using Ireland as a case study. Journal of sustainable renewable energy, 15(4), 2123-2133. Https://doi.org/10.1016/j.rser.2011.01.015 .

Del, R., \& Burguillo, P.M. (2009). An empirical analysis of the impact of renewable energy development on local sustainability. Journal of sustainable energy, 13(6-7), 1314- 1325. https://doi.org/10.1016/j.rser.2008.08.001 .

Douglass, M. (1998 A regional network strategy for reciprocal rural - urban linkages: an agenda for policy research with reference to Indonesia. Third World Planning Review, 20(1), 1 - 35..

Eyben, R., Kabeer, N., \& Cornwall, A. (2008). Conceptualizing empowerment and the implications for pro-poor growth: A paper for the DAC Poverty Network. Brighton: IDS.

Fujikake, Y. (2008). Qualitative Evaluation: Evaluating People's Empowerment . Japanese Journal of Evaluation Studies, 8(2), 25 - 37.

Gado, A., \& El-Zeftawy, A. (2009). Design and economy of renewable energy sources to supply isolated loads in rural and remote areas of Egypt. In: Proceedings of the 20th International Conference and Exhibition on Electricity Distribution - Part 1 (CIRED 2009), 1-4.

Caring. (1991). Social Psychology. Bandung: PT. Eresco.

Goldemberg, J. (2007). Ethanol for a sustainable energy future. Journal of Science, 315(5813), 808-810. https://doi.org/10.1126/science.1137013.

Gomez, M., \& Silveira, S. (2010). Rural electrification of the Brazilian Amaze $n$ the achievements and lessons. Energy policy, 38(10), 6251-6260.

Gurbuz, G., \& Aykol, S. (2008). Entrepreneurial intentions of young educated public in Turkey. Journal of Global Strategic Management, 2(2), 47 - 56

Haas, R., Watson, J., \& Eichhammer, W. (2008). Transitions to sustainable energy systems special introduction to the energy policy issue. Energy policy, 36(11), 4009-4011. https://doi.org/10.1016/j.enpol.2008.06.015. 
Hardiani, H., Hastuti, D., \& Junaidi, J. (2019). An analysis of the attitudinal, contextual and gender perspectives of the entrepreneurial intentions among Indonesian millennials. Malaysian Management Journal, 23, 135-150.

Hardiani, J., Prihanto, P.H. \& Junaidi, J. (2019). The Influence of Socioeconomic Characteristics and Family Support on the Quality of Life and Well-Being of the Elderly in Jambi Province, Indonesia. International Journal of Social Sciences and Management, 6(3), 63 - 74

Hendratmoko C., \& Marsudi H. (2010). Analysis of Socio-Economic Empowerment Level of Capture Fishermen in Cilacap Regency. Journal of Socio-Economic Dynamics, 6(1), 1-17.

Hillebrand, B., Buttermann, H.G., Behringer, J.M., \& Bleuel, M. (2006). The expansion of renewable energy and employment effects in Germany. Journal of energy policy, 34(18), 3484-3494. https://doi.org/10.1016/j.enpol.2005.06.017.

Hisrich, R.D. \& Peters, M.P. (1998). Entrepreneurship. Boston: McGraw Hill.

Hoffmann, D. (2009). Creation of regional added value by regional bioenergy resources. Journal of Renewable Sustainable Energy, 13(9), 2419-2429. https://doi.org/10.1016/j. rser.2009.04.001 .

Horton, P.B., \& Hunt, C.L. (2006). Sosiologi (Ram, A.,Trans.). Jakarta: Erlangga Publisher.

Hua X., Yan J., \& Zhang, Y. (2017). Evaluating The Role of Livelihood Assets in Suitable Livelihood Strategies: Protocol for anti-poverty policy in the Eastern Tibetan Plateau, China . Ecological Indicators , 78, 62-74.

Hubeis, A.V.S., Priono, M., Sedyaningsih, S., Ace S., Bintari, A., Yanis, E., \& Mintarti. (2007). Communication Innovation. Issue 2. Jakarta: Open University Publisher.

Hurlock, E.B. (2006). Developmental Psychology: a development throughout the life span. Jakarta: Erlangga Publisher.

Hurlock., E.B. (1980). Developmental Psychology: An Approach Throughout the Life Span. Jakarta: Erlangga Publisher.

Katti, P.K., \& Khedkar, M.K. (2005). Towards sustainable energy systems: integrating renewable energy sources is the key to rural area power supply. Proceedings of the 7th International Power Engineering Conference (IPEC), 1.

Kuncono, O.S. (2013) . Effect of Confucius Ethics on Entrepreneurship, Business Capability and Business Performance of Chinese Ethnic Retailers in Surabaya. Dissertation. Airlangga University.

Lehr, U., Nitsch, J., Kratzat, M., Lutz, C., \& Edler, D. (2008). Renewable energy and employment in Germany. Energy Policy, 36(1), 108- 117. https://doi.org/10.1016/j. enpol.2007.09.004 .

Lionberger, H.F \& Gwin, P.H. (1982). Communication strategies: A guide for agricultural change agents. Ilinois, United States of America: The Interstate Pinters \& Publisher Inc.

Mardikanto, T. (1993). Penyuluhan Pembangunan Pertanian. Surakarta: Sebelas Maret University Press.

Masini, A., \& Menichetti, E. (2012). The impact of behavioral factors in renewable energy investment decisions making process: conceptual framework and empirical findings. Energy policy, 40, 28-38. https://doi.org/10.1016/j.enpol.2010.06.062.

Meredith., Geoffrey, G., Robert, E., Nelson., Philip, A., Nick. (2000). Kewirausahaan: Teori dan Praktek. (Asparsayogi, A., Trans.) Jakarta: Pustaka Binaman Pressindo. 
Monks, FJ., Knoers, AMP., Had itono, SR. (2001). Developmental psychology: Introduction in various parts. Yogyakarta: Gadjah Mada University.

Moreno, B., Lopez, AJ (2008). The effect of renewable energy on employment. The case of Austria (Spain). Renewable and sustainable energy, 12(3), 732- 571. Https://doi.org/10.1016/j.rser.2006.10.011.

Nuskhi, M., \& Setiana, L. (2004). Factors affecting the entrepreneurial attitudes of dairy farmers in Banyumas Regency. Journal of rural development, 4(3), 17-20.

Openshaw, K. (2010). Biomass energy: Employment generation and its contribution to poverty alleviation. Journal of Biomass Bioenergy, 34(3), 365-378. Https://doi.org/10.1016/j.biombioe.2009.11.008.

Page, N., \& Czuba, C.E. (1999). Empowerment: What Is It? Journal of Extension, 37(5). http://www.joe.org/joe/2006august/rb4.php.

Peura, P., \& Hyttinen, T. (2011). The potential and economics of bioenergy in Finland. J.Clean. Prod, 19(9-10), 927- 945. Https://doi.org/10.1016/j.jclepro.2011.02.009.

Peura, P., Kuittinen, H., Knuckey, L., Goodall, L., \& Dinta, L. (2014). Implement sustainable energy for case studies. International Journal of a sustainable economy , 6(1), 19-44. Https://doi.org/10.1504/IJSE.2014.058516.

Rachmawatie, D. (2005). Analysis of Farmer Decisions in Adopting Artificial Insemination Technology. (Master's thesis). Bogor. Faculty of Animal Husbandry. Bogor Agricultural Institute.

Rogers, E.M., \& Shoemaker, F.F. (1971). Communication of Innovation: a cross-cultural approach, New York: United States of America: Free Press.

Rowlands, J. (1995). Examined Empowerment. Development in practice, 5(2), 101-107.

Santrock, J.W. (2008). Educational Psychology. Jakarta: Kencana Prenanda Media Group Publisher.

Sastresa, E.L., Uson, A.A., Bribi, I.Z., \& Scarpellini, S. (2010). Local impact of renewable on employment: methodology and case study assessment. Journal of renewable energy sustainable energy, 14(2), 679- 690. Https://doi.org/10.1016/j.rser.2009.10.017 .

Shyu, C. (2014). Ensuring access to electricity and minimum basic electricity needs as a goal for the post-MDG development agenda after 2015. Energy for sustainable development, 19, 29-38.

Smith, B., Burton, I., Klein, R.J.T., \& Street, R. (1999). The Science of Adaptation: A Fremework for Assessment. Mitigation and Adaptation Strategies for Global Change, 4, 199-213.

Sobur, A. (2009). General Psychology. Bandung: CV. Faithful Reader.

Spencer, L.M., \& Spencer, S.M. (1993). Competence Work: Model for superior performance. New York: John Wiley and Sons, Inc.

Stewart, J. (1994). Empowering people. London: Pustman Publishing .

Suharti, L. \& Sirine, H. (2011). Faktor-Faktor yang Berpengaruh Terhadap Niat Kewirausahaan (Entrepreneurial Intention) (Studi Terhadap Mahasiswa Universitas Kristen Satya Wacana, Salatiga). Jurnal Manajemen dan Kewirausahaan, 13(2), 124-134.

Thomley, P., Rogers, J., \& Huang, Y. (2008). Quantification of employment from biomass power plants. Renewable energy, 33(8), 1922 - 1927. Https://doi.org/10.1016/j.renene.2007.11.011. 
Tridakusumah, A.C., Elfina, M., Murdiyaningsih, D.I., Pioke, J., \& Bumulo S. (2015). Pola Adaptasi Ekologi dan Strategi Nafkah RumahTangga di Desa Pangumbahan. Sodality: Jurnal Sosiologi Pedesaan, 3(3), 85-90.

Ul Haq, M. (1995). Reflection on human development. United Kingdom: Oxford University Press.

Valer, L.R., Mocelin, A., Zilles, R., Moura, E., \& Nascimento, A.C.S. (2014). Assessment of socioeconomics impact of access to electricity in the Brazilian Amazon: a case study in two communities in Mamiraua Reserve. Energy for sustainable development, 20, 58-65.

Wang, J.J., Jing, Y.Y., Zhang, C.F., \& Zhao, J.H. (2009). Review of multi-criteria decision analysis aid in sustainable energy decision-making. Journal of sustainable renewable energy, 13(9), 2263-2278. 